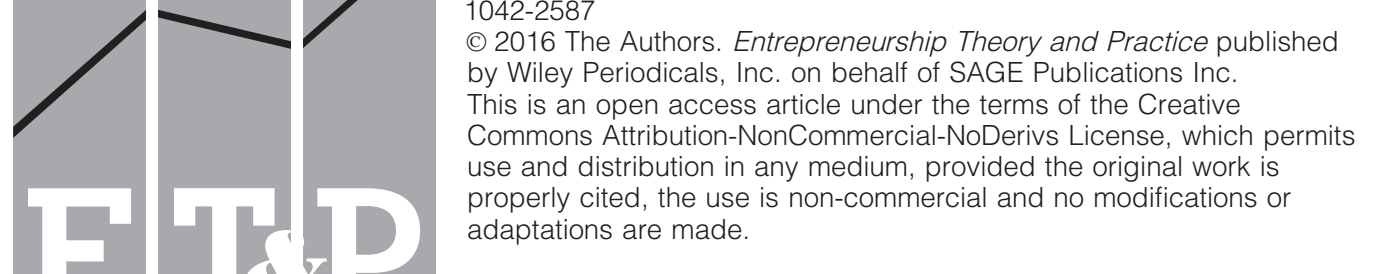

\title{
A Careers Perspective on Entrepreneurship
}

\author{
M. Diane Burton \\ Jesper B. Sørensen \\ Stanislav D. Dobrev
}

\section{Introduction}

What if being an entrepreneur were treated like any other occupation-teacher, nurse, manager? What if the decision to found a new venture were thought of as one of many options that individuals consider as they try to structure a meaningful and rewarding career? How would the field of entrepreneurship research be different? In our view, there is much to be learned by conceiving of entrepreneurship not solely as a final destination, but as a step along a career trajectory. Doing so opens the study of entrepreneurship to a wider range of scholarly insights, and promises important insights for entrepreneurial practice, training, and policy. This special issue takes an important step in this direction.

To date, a primary focus of entrepreneurship scholars has been on the founding of a new venture as an end in and of itself, or more generally on transitions to entrepreneurship. There can be no doubt that this is an important and fruitful area of research, one that we each have contributed to ourselves. However, as life course scholars have long recognized, "transitions are always embedded in trajectories that give them distinctive form and meaning" (Elder, 1985, p. 31). Work transitions, in other words, should be understood in the context of a career- "career" both in the sense of a sequence of past states, and in the sense of an imagined future trajectory. For example, many researchers approach the question of who becomes an entrepreneur by examining the characteristics of the people who become entrepreneurs rather than the characteristics of the pathways that lead to entrepreneurship. To the extent that researchers have considered the role of career experiences, these experiences have been conceptualized as accumulated human capital rather than a series of steps that may or may not build on one another (Spilerman, 1977).

Too strong an emphasis on state transitions risks making the destination state seem wholly unique if not idiosyncratic. Few journal pages are devoted to the study of why someone becomes a plumber or an accountant or a teacher. Instead those outcomes are studied as specific instances of a more general career mobility process. There are, of course, good reasons to devote specific attention to entrepreneurship as an outcome, given its critical role in innovation and economic growth. But focusing on entrepreneurship in

Please send correspondence to: M. Diane Burton, tel.: 607-255-8187; e-mail: burton@cornell.edu. 
isolation risks emphasizing everything that is different about entrepreneurship and losing sight of all of the ways in which movement into and out of entrepreneurship is similar to other career transitions. ${ }^{1}$ Many people who become accountants or teachers later become entrepreneurs, and vice versa. By losing sight of the commonalities between different types of transitions, we impoverish our understanding of what is truly unique about the entrepreneurial transition.

This volume represents an important step toward more systematically considering entrepreneurship from a career perspective and focusing attention on the context of entrepreneurship, especially the organizations and institutions that shape it and the career paths that surround it. In developing this special issue of Entrepreneurship Theory and Practice, we drew upon the emerging literature on employee mobility and entrepreneurship (cf. Sørensen \& Sharkey, 2014). This growing body of work starts by acknowledging that most entrepreneurs have experience working in other organizations prior to founding a new firm (Dobrev \& Barnett, 2005; Freeman, 1986; Sørensen \& Fassiotto, 2011) and builds on the recognition that some firms generate more entrepreneurs than others (Burton, Sørensen, \& Beckman, 2002; Elfenbein, Hamilton, \& Zenger, 2010; Gompers, Lerner, \& Scharfstein, 2005; Klepper \& Sleeper, 2005; Sørensen, 2007a). These insights, combined with recent efforts to consider how work experiences and organizational contexts can be contexts that shape and constrain future actions (Nanda \& Sørensen, 2010; Roach \& Sauermann, 2015), start to offer a more expansive view of entrepreneurship, organizations, and their interrelationships. The next step is to adopt a careers perspective and engage in a more dedicated inquiry into how entrepreneurship intersects with and impacts individual career trajectories and outcomes.

In editing this volume, we sought to complement earlier approaches to entrepreneurial careers (e.g., the 1994 Special Issue of ETP edited by Jerome Katz and Edgar Schein), which were grounded in psychological approaches to career theory and emphasized stable individual traits, with structural approaches that emphasize organizational context and change. We were impressed by the enthusiastic response to our call for papers: almost 70 papers were submitted, covering a wide range of approaches and of very high quality overall. There is clearly great interest in the topic of entrepreneurship, organizations, and careers. We were particularly pleased to note the number of papers that took a structural view of careers and entrepreneurship and borrowed from sociology and labor economics-approaches that differed from the more traditional studies of entrepreneurial attitudes or intentions. By focusing on these themes, we sought to bring alternative theory, methods, and data to the forefront. In line with our call for papers, we explicitly prioritized theoretical and empirical work that would advance our understanding of the multiple ways in which career experiences shape entrepreneurial activity, and the ways in which entrepreneurial activity shapes career experiences. In the end, after a careful review process, we selected the eight papers included in this volume. They are exemplars of the careers perspective on entrepreneurship and together reveal how this new approach — which is enabled by new kinds of data and brings with it new theoretical and methodological tools_-will generate new insights about entrepreneurship and careers.

1. A simple example of the failure to consider how transitions to entrepreneurship share features common to other job transitions lies in choices about how to model the transition rate. It is well known that job turnover rates decline with tenure (e.g., Jovanovic, 1979). As a result, scholars should-but in our experience often do not-use this as a baseline for understanding transitions to entrepreneurship (Sørensen and Sharkey, 2014). 


\section{Careers and Entrepreneurship}

Movements between entrepreneurship and paid employment-including both transitions to entrepreneurship and re-entry into paid employment-are remarkably common, yet have only recently begun to attract scholarly attention. Ferber and Waldfogel (1998) estimate that a quarter of young men and a fifth of young women in the United States have experienced entrepreneurship by their mid-thirties. Far more individuals have contemplated launching a new venture (Reynolds \& Curtin, 2008). The vast majority of entrepreneurs launch their new ventures after having worked for established firms (Beckman \& Burton, 2008; Sørensen \& Fassiotto, 2011). And while between $15 \%$ and $30 \%$ of entrepreneurs are serial founders who follow one venture with another (Hyytinen \& Ilmakunnas, 2007), the remaining necessarily have a different kind of career transition. These mobility patterns reveal that the majority of entrepreneurs experience founding a new venture as a period of time, or spell, within a career. Even serial entrepreneurs can be viewed as having a series of distinct entrepreneurial experiences that have beginnings and endings.

This suggests that entrepreneurial activity can be usefully studied using a perspective that explicitly conceptualizes the relationship between entrepreneurial dynamics, labor market processes, and career trajectories. In this section, we briefly review different sociological approaches to careers, and consider their implications for the study of entrepreneurship.

Sociology offers two distinct theoretical approaches to careers: attainment and stage passages (see Barley [1989] for an overview and comparison). The attainment approach views a career as an ordered sequence of work experiences. Movement through this sequence represents progress and advancement. The attainment tradition relies on notions of steps, advancement, and opportunity, and is primarily focused on careers that progress within and between formal organizations. Career researchers working in the attainment tradition consider how far people progress along a career path and how quickly they achieve desired outcomes, and whether different categories of people-gender, race, ethnicity, age, class background-have similar outcomes. Sørensen and Sharkey (2014) develop a model of entrepreneurial entry rooted in an attainment model of careers, asking how the availability of advancement opportunities within and between organizations condition the choice of entrepreneurship.

The stage passages approach to careers has its roots in ethnographic studies of professions such as medicine and law, but has expanded as an analytic tool to studies of a number of nonwork identities such as drug users, healthcare patients. The focus of the stage passages approach is on transitions and transformations, with demarcated beginnings and ends that are recognizable by the incumbent experiencing them as well as by societal observers. As Barley (1989, p. 50) describes, "A status passage connotes not only a temporally staged shift from one social role to another but also a fundamental change in an individual's identity." The idea of entrepreneurship as an identity transformation has been picked up with enthusiasm by entrepreneurship scholars (see Hoang and Gimeno [2010] for an excellent example). Dobrev and Barnett (2005) reckoned that identity dissonance drives the transition from entrepreneurship to paid employment among founders as their ventures develop in time and space. Yet other useful ideas from the stage passages perspective have laid fallow. For example, some status passages, like the transition to adulthood, are inevitable and irreversible whereas others, like moving from being healthy to sick or from being ill to well, represent movements across more or less desirable statuses and ones that may or may not be repeated or reversed. This raises questions of path 
dependency, and the repeatability and reversibility of different transitions-questions that are rarely examined in the entrepreneurship literature.

Within the status passage tradition of careers research, there is conscious attention to the ways in which a career connects individuals to broader social institutions-including formal organizations, government, and family - and is also shaped by those institutions. As Abbott and Hrycak (1990, p. 147) argue, individuals "try to structure their work histories into careers that they find culturally acceptable, into patterns that they recognize." This suggests that entrepreneurship may serve different functions in the career for different people, depending on how their careers have evolved to a point in time, and on which patterns they recognize and value. Consistent with this, the literature on the effects of parental self-employment (Sørensen, 2007b) can be interpreted as demonstrating how exposure to self-employment as a career option makes that career pattern more available and attractive.

Many careers culminate in a transition to entrepreneurship, and this is likely a widely shared normative model of the ideal-typical entrepreneurial career. Yet a fascinating aspect of entrepreneurship as a socially recognized and legitimated role is that multiple normative models of entrepreneurial careers exist. Compare, for example, entrepreneurship to other widely understood career choices such as physician, lawyer, or carpenter. These alternative career paths are characterized by a strong normative age-grading; someone who wants to be a doctor understands the sequence and timing of decisions that are required to pursue this path. In particular, these roles typically involve a series of choices in young adulthood; very few people become doctors as a second career. Entrepreneurship, however, seems characterized by much more heterogeneity. In addition to images of entrepreneurship as the culmination of a career in paid employment, the popular imagination is captured by stories of start-ups launched by high school and college studentsthink Mark Zuckerberg or Steve Jobs. Similarly, many business schools are populated by students whose primary goal is to become entrepreneurs upon graduating. Finally, for many, entrepreneurship may not be a destination so much as bridge between different career opportunities (Earle \& Sakova, 2000). Entrepreneurship may be a bridge for a variety of reasons. An individual may enter entrepreneurship intending it to be an end-state, but find that they are not capable of succeeding. Or, entrepreneurship may simply be viewed as a stop-gap measure, the best job available at a particular time. In yet other cases, the very success of the venture may propel an entrepreneur to exit as organizational growth inevitably decreases the social influence inherent in the role of the founder (Dobrev \& Barnett, 2005; Wasserman, 2003). In short, for many the entrepreneurial role is transitional, entered into because it is the best of the opportunities available, and abandoned when other, more promising opportunities present themselves.

\section{Bringing Career Theory Into Entrepreneurship Research}

While the attainment and status passage approaches to careers are very different in style, tone, and methodology, they have a number of things in common. Both focus on the way life events unfold over time and are, therefore, dynamic perspectives. Both view careers in terms of a series or sequence of steps or stages and attend to transitions into and out of particular a given step or stage. Both embed a comparative perspective and consider how a career is viewed in contrast to other alternatives. Finally, both raise questions about the fundamental nature of different career stages and attend to the broader institutional and organizational context. As such, they have much to offer entrepreneurship researchers who are interested in careers. 


\section{Entrepreneurship as a Transient State}

To date most of the entrepreneurship research has treated entrepreneurship as a final destination. In the language of Markov chains, entrepreneurship is typically treated as an "absorbing state" as opposed to a "transient state." In treating entrepreneurship as an absorbing state, scholars focus attention on what comes before and fail to see the possibility of subsequent transitions. It is not surprising, then, that entrepreneurship scholars have paid relatively little attention to the potential for movement from entrepreneurship back into wage employment or to unemployment. In our view, however, entrepreneurship should be viewed more like marriage than like death; exit is possible and indeed common. Considering entrepreneurship as a step along a career path as opposed to always a final destination opens a number of new research questions: What leads to it and where does it lead? When do people enter/exit from it? Are durations different? When and for whom is it a final destination? Does becoming a founder represent upward, downward, or lateral mobility?

In this reframing entrepreneurship as a potentially transient state, we can borrow the analytic tools used to study spells and transitions in other fields and disciplines such as studies of unemployment from labor economics, studies of organizational change and disbanding from organizational ecology, and studies of cohabitation or marriage from demography and studies of disease from epidemiology. All of these kinds of studies pose questions about timing, propensity, duration, and consequence. Two of the papers in this volume take such an approach. Blumberg and Pfann (2016) examine what they term the "gestation period" of entrepreneurship comparing people from family business backgrounds with those from wage-earner family backgrounds. Luzzi and Sasson (2016) follow entrepreneurs into their postentrepreneurship jobs and find that future wages are positively associated with entrepreneurial firm performance.

\section{Entrepreneurship as a Career Choice}

A careers perspective on entrepreneurship emphasizes its situated nature and how it compares to other employment-related choices (Douglas \& Shepherd, 2002). It is a job choice that can be analyzed in terms of wages, skills, and mobility. Entrepreneurs appear to be drawn from both tails of the ability distribution (Åstebro \& Thompson, 2011; Blanchflower, 2000). This is consistent with research demonstrating no relationship between educational attainment and entrepreneurship. It is also consistent with theories that suggest there are two types of entrepreneurship: necessity-based (e.g., Borjas \& Bronars, 1989; Joona \& Wadensjo, 2013) and opportunity-driven-some are pushed into entrepreneurship because they lack other whereas others pursue entrepreneurial opportunities when they perceive the potential rewards to be greater than those obtained from wage employment options (e.g., Carnahan, Agarwal, \& Campbell, 2012; Gimeno, Folta, Cooper, \& Woo, 1997; Hartog, Van Praag, \& Van Der Sluis, 2010; Joona \& Wadensjo; Lofstrom, Bates, \& Parker, 2014; Sørensen \& Sharkey, 2014). This volume opens with an article by Berkjout, Hartog, and van Praag (2016) that takes the next step in this line of reasoning to ask how structural features of the wage distribution within an occupation, and hence the opportunity cost of leaving that occupation, impact entrepreneurial propensities.

A careers perspective also focuses attention on human capital accumulation both before, during, and after a period of entrepreneurship. A long tradition in entrepreneurship research relies on human capital theory to address the relationship between prior experiences and entrepreneurial outcomes (cf. Unger, Rauch, Frese, \& Rosenbusch, 2011). But 
the findings from this literature are somewhat inconsistent. For example, some authors suggest that individuals who have diverse skills and experiences are more likely to both enter and be successful in entrepreneurship (Åstebro \& Thompson, 2011; Dobrev \& Barnett, 2005; Lazear, 2004, 2005), whereas others find that people tend to found businesses in the same industry in which they were previously employed (Klepper \& Sleeper, 2005; Sorenson \& Audia, 2000) and this prior experience seems to be associated with better venture outcomes (Brüderl, Preisendörfer, \& Ziegler, 1992; Chandler, 1996; Delmar \& Shane, 2006; Eesley \& Roberts, 2012; Gompers et al., 2005). Adopting a careers perspective has the potential to shed light on these inconsistencies by attending to the ordering of experiences, their durations, as well as similarities and differences across positions and organizations. We can also begin to examine how the entrepreneurial experience in and of itself contributes to skills and abilities and the consequences this has for future career opportunities (e.g., Campbell, 2013; Parker, 2013; Toft-Kehler, Wennberg, \& Kim, 2014).

Several of the papers in this volume consider how prior experiences shape entrepreneurial entry by carefully considering experience diversity and variety across industries, occupations, and geographies. Chen and Thompson (2016), for example, extend previous empirical work on Lazear's jack-of-all-trades theory using online CVs from a professional networking website, and find that variety in employers and jobs is positively associated with entry into entrepreneurship. Their careful analysis is an exemplar in terms of unpacking the complex interrelationships between mobility, skill acquisition, and firm characteristics and their effects on entry. Astebro and Yong (2016) examine how diverse career experiences may have contrasting effects of innovative creativity and entrepreneurial viability, with high levels of occupational or industrial diversity leading to more innovative ideas, but diverse industry experiences being detrimental to entrepreneurial earnings. Frederiksen, Wennberg, and Balachandran (2016), using comprehensive register-based data from Sweden, similarly find that mobility is positively associated with entrepreneurial entry, but not with entrepreneurial success. Finally, Hsieh (2016) makes an important contribution to this line of work by considering the role of sequencing, i.e., whether different business functions are experienced sequentially or in parallel. Analyses of the careers of scientists and engineers suggest that parallel experiences enable individuals to better draw connections across domains.

\section{Entrepreneurship as a Life Stage}

In considering the unfolding nature of entrepreneurial careers, we can begin to ask questions about how entrepreneurship interacts with other stages and transitions. Most of the existing research also emphasizes stable individual traits. For example, gender and family circumstances are known to be correlated with entrepreneurship: Men are more likely to become entrepreneurs than women; married people more likely than singles; those from entrepreneurial families more likely than those from wage-worker families (Aldrich \& Kim, 2007; Berglann, Moen, Røed, \& Skogstrøm, 2011; Dunn \& HoltzEakin, 2000; Fairlie \& Robb, 2007; Parker, 2008; Sørensen, 2007b).

A careers perspective shifts our attention toward things that change over time such as family and organizational context. This presents an opportunity to take into account life course and temporal differences across individuals and to further examine the extent to which individual and organization-level outcomes are interrelated. For example, one unexplored research direction may be to evaluate how working side by side with the organization's founders affects the propensity of other employees to consider starting 
their own ventures. And popular trends in organizations research investigating the social construction of organizational creativity and authenticity may benefit from considering whether such organization-level features are more likely when the original founder remains with her organization. As Dobrev and Barnett (2005, p. 447) surmise, "theories of entrepreneurship have the greatest opportunity to advance if they explicitly allow for the fact that different organizational contexts either retard or stimulate foundings, and that these effects hinge on the roles of individuals."

Entrepreneurship is a life-course-related choice that may interact with other decisions such as marriage and fertility (Davis \& Shaver, 2012). It may be a choice that can be revisited as both personal and environmental situations shift, or alternatively, it may be associated with path dependencies that make it difficult to transition into or out of (Dyer, 1994). For example, in this volume, Thebaud (2016) considers how passing up a prior career opportunity changes the propensity to be self-employed. She finds that women who have made career sacrifices for their family have a higher likelihood of becoming entrepreneurs. Founding a firm can also be treated as an attained status-like earning an advanced degree-where we can study who does it, how long it takes, and among those who start, who completes? For example, Blumberg and Pfann (2016) compare people from family business backgrounds to those who do not and finds that they have different patterns of entrepreneurial entry. All of these kinds of question take a careers perspective to entrepreneurship and are fruitful avenues for future research.

\section{Conclusion}

The papers in this volume are about entry into entrepreneurship, success in the role, and postentrepreneurial career outcomes. They study entrepreneurship in different countries and draw on a mix of data types: cross-sectional surveys, panel surveys, longitudinal surveys, and administrative data. Note how the careers perspective that we are advancing benefits from a longitudinal approach and is enabled by the availability of new kinds of databases and will continue to be enhanced as we are able to draw cross-national comparisons. There is variation in how the authors have defined entrepreneurship and measured outcomes, but we see a strong tendency to study self-employment and wages. Some might view this as a weakness, since only a small share of transitions to self-employment generate high-growth ventures. We would note, however, that the transition to selfemployment is the most critical differentiator between entrepreneurship and other career transitions. As Sørensen and Sharkey (2014) note, "the most elemental act of entrepreneurship is an individual's decision to forgo paid employment and assume the responsibility and risk of operating a new venture."

We view the papers in this special issue as an important accomplishment in defining a career perspective on entrepreneurship, but more importantly hope that the papers serve as inspiration for future students of entrepreneurship. The papers in this volume represent different kinds of contributions and advances. Some use unusual data (Åstebro \& Yong, 2016; Chen \& Thompson, 2016). Some bring novel methods or develop new measures (Chen \& Thompson; Hsieh, 2016). Some introduce new conceptual ideas (Blumberg \& Pfann, 2016; Hsieh, 2016; Thebaud, 2016), some incorporate insights from other fields such as gendered institutions (Thebaud) and opportunity costs (Berkhout et al., 2016). Some bring rigorous empirical evidence to long-standing questions in entrepreneurship research (Frederiksen et al., 2016) and some ask new questions (Luzzi \& Sasson, 2016). But one unifying theme that runs through all the papers in this special issue is the compelling appreciation for the fact that the creation of new organizations is among the most important forces of social and economic 
development. Entrepreneurship is a milestone event not only in the careers of those who undertake it but also for those who find employment in new ventures. We hope that the insights presented here will further stimulate research tying entrepreneurs' individual careers to broader processes of expanding social mobility and economic attainment.

\section{REFERENCES}

Abbott, A., \& Hrycak, A. (1990). Measuring resemblance in sequence data: An optimal matching analysis of musicians' careers. American Journal of Sociology, 96(1), 144-185.

Aldrich, H.E., \& Kim, P.H. (2007). A life course perspective on occupational inheritance: Self-employed parents and their children. In M. Ruef \& M. Lounsbury (Eds.), Research in the sociology of organizations (pp. 33-82). Amsterdam: JAI Press.

Åstebro, T., \& Thompson, P. (2011). Entrepreneurs, jacks of all trades or hobos? Research Policy, 40, 637-649.

Åstebro, T., \& Yong, K. 2016. Invention quality and entrepreneurial earnings: The role of prior employment variety. Entrepreneurship Theory and Practice, 40(2), 381-400.

Barley, S.R. (1989). Careers, identities, and institutions: The legacy of the Chicago School of Sociology. In M.B. Arthur, D.T. Hall, \& B.S. Lawrence (Eds.), Handbook of career theory (pp. 41-65). Cambridge: Cambridge University Press.

Beckman, C.M., \& Burton, M.D. (2008). Founding the future: Path dependence in the evolution of top management teams from founding to IPO. Organization Science, 19(1), 3-24.

Berglann, H., Moen, E.R., Røed, K., \& Skogstrøm, J.F. (2011). Entrepreneurship: Origins and returns. Labour Economics, 18(2), 180-193.

Berkhout, P., J. Hartog, \& van Praag, M. 2016. Entrepreneurship and financial incentives of return, risk and skew. Entrepreneurship Theory and Practice, 40(2), 249-268.

Blanchflower, D.G. (2000). Self-employment in OECD countries. Labour Economics, 7(5), 471-505.

Blumberg, B., \& Pfann, G. 2016. Roads leading to self-employment: Comparing transgenerational entrepreneurs and self-made start-ups. Entrepreneurship Theory and Practice, 40(2), 335-357.

Borjas, G.T., \& Bronars, S.G. (1989). Consumer discrimination and self-employment. Journal of Political Economy, 97(3), 581-605.

Brüderl, J., Preisendörfer, P., \& Ziegler, R. (1992). Survival chances of newly founded business organizations. American Sociological Review, 57(2), 227-242.

Burton, M.D., Sørensen, J.B., \& Beckman, C.M. (2002). Coming from good stock: Career histories and new venture formation. In M. Lounsbury (Ed.), Research in the sociology of organizations (Vol. 19, pp. 229-262). Bingley, U.K.: Emerald Publishing.

Campbell, B.A. (2013). Earnings effects of entrepreneurial experience: Evidence from the semiconductor industry. Management Science, 59(2), 286-304.

Carnahan, S., Agarwal, R., \& Campbell, B.A. (2012). Heterogeneity in turnover: The effect of relative compensation dispersion of firms on the mobility and entrepreneurship of extreme performers. Strategic Management Journal, 33(12), 1411-1430.

Chandler, G.N. (1996). Business similarity as a moderator of the relationship between pre-ownership experience and venture performance. Entrepreneurship Theory and Practice, 20, 51-65. 
Chen, L., \& Thompson, P. 2016. Skill balance and entrepreneurship: Evidence from online career histories. Entrepreneurship Theory and Practice, 40(2), 289-305.

Davis, A.E., \& Shaver, K.S. (2012). Understanding gendered variations in business growth intentions across the life course. Entrepreneurship Theory and Practice, 36(3), 495-512.

Delmar, F., \& Shane, S. (2006). Does experience matter? The effect of founding team experience on the survival and sales of newly founded ventures. Strategic Organization, 4, 215-247.

Dobrev, S.D., \& Barnett, W.P. (2005). Organizational roles and transition to entrepreneurship. Academy of Management Journal, 48(3), 433-449.

Douglas, E. J., \& Shepherd, D.A. (2002). Self-employment as a career choice: Attitudes, entrepreneurial intentions, and utility maximization. Entrepreneurship: Theory \& Practice, 26(3), 81-90.

Dunn, T., \& Holtz-Eakin, D. (2000). Financial capital, human capital, and the transition to self-employment: Evidence from intergenerational links. Journal of Labor Economics, 18, 282-305.

Dyer, W.G. (1994). Toward a theory of entrepreneurial careers. Entrepreneurship Theory and Practice, 19(2), 7-22.

Earle, J.S., \& Sakova, Z. (2000). Business start-ups or disguised unemployment? Evidence on the character of self-employment from transition economies. Labour Economics, 7(5), 575-601.

Eesley, C., \& Roberts, E.B. (2012). Are you experienced or are you talented? When does innate talent vs. experience explain entrepreneurial performance? Strategic Entrepreneurship Journal, 6, 207-219.

Elder, G.H. (1985). Perspectives on the life course. Ithaca, NY: Cornell University Press.

Elfenbein, D.W., Hamilton, B.H., \& Zenger, T.R. (2010). The small firm effect and the entrepreneurial spawning of scientists and engineers. Management Science, 56(4), 659-681.

Ferber, M., \& Waldfogel, J. (1998). The long-term consequences of non-standard work. Monthly Labor Review, 121(5), 3-12.

Fairlie, R.W., \& Robb, A. (2007). Families, human capital, and small business: Evidence from the characteristics of business owners survey. Industrial and Labor Relations Review, 60(2), 225-245.

Frederiksen, L., K. Wennberg, \& Balachandran, C. 2016. Mobility and entrepreneurship: Evaluating the scope of knowledge-based theories of entrepreneurship. Entreprenurship Theory and Practice, 40(2), $359-380$.

Freeman, J. (1986). Entrepreneurs and organizational products: Semiconductor firms and venture capital firms. In G.D. Libecap (Ed.), Advances in the study of entrepreneurship, innovation, and economic growth (pp. 33-52). Greenwich, CT: JAI Press.

Gimeno, J., Folta, T.B., Cooper, A.C., \& Woo, C.Y. (1997). Survival of the fittest? Entrepreneurial human capital and the persistence of underperforming firms. Administrative Science Quarterly, 42, 750-783.

Gompers, P., Lerner, J., \& Scharfstein, D. (2005). Entrepreneurial spawning: Public corporations and the genesis of new ventures, 1986-1999. Journal of Finance, 60(2), 577-614.

Hartog, J., Van Praag, M., \& Van Der Sluis, J. (2010). If you are so smart, why aren't you an entrepreneur? Returns to cognitive and social ability: Entrepreneurs versus employees. Journal of Economics \& Management Strategy, 19(4), 947-989.

Hoang, H., \& Gimeno, J. (2010). Becoming a founder: How founder role identity affects entrepreneurial transitions and persistence in founding. Journal of Business Venturing, 25(1), 41-53. 
Hsieh, C. 2016. Do the self-employed more likely emerge from sequential or parallel work experience in business-related functions? Entrepreneurship Theory and Practice, 40(2), 307-334.

Hyytinen, A., \& Ilmakunnas, P. (2007). What distinguishes a serial entrepreneur? Industrial and Corporate Change, 16(5), 793-821.

Joona, P.A., \& Wadensjo, E. (2013). The best and the brightest or the least successful? Self-employment entry among mail wage-earners in Sweden. Small Business Economics, 40, 155-172.

Jovanovic, B. (1979). Job matching and the theory of turnover. Journal of Political Economy, 87(5), 972-990.

Klepper, S., \& Sleeper, S. (2005). Entry by spinoffs. Management Science, 51(8), 1291-1306.

Lazear, E.P. (2004). Balanced skills and entrepreneurship. American Economic Review, 94, 208-211.

Lazear, E.P. (2005). Entrepreneurship. Journal of Labor Economics, 23(4), 649-680.

Lofstrom, M., Bates, T., \& Parker, S.C. (2014). Why are some people more likely to become smallbusinesses owners than others: Entrepreneurship entry and industry-specific barriers. Journal of Business Venturing, 29(2), 232-251.

Luzzi, A., \& Sasson, A. 2016. Individual enterpreneurial exit and earnings in subsequent paid employment. Entrepreneurship Theory and Practice, 40(2), 401-420.

Nanda, R., \& Sørensen, J.B. (2010). Workplace peers and entrepreneurship. Management Science, 56(7), $1116-1126$.

Parker, S.C. (2008). Entrepreneurship among married couples in the United States: A simultaneous probit approach. Labour Economics, 15, 515-537.

Parker, S.C. (2013). Do serial entrepreneurs run successively better-performing businesses? Journal of Business Venturing, 28(5), 652-666.

Reynolds, P.D., \& Curtin, R.T. (2008). Business creation in the United States: Panel study of entrepreneurial dynamics II initial assessment. Foundations and Trends in Entrepreneurship, 4, 155-307.

Roach, M., \& Sauermann, H. (2015). Founder or joiner: The role of preferences and context in shaping different entrepreneurial interests. Management Science, 61(9), 2160-2184.

Sørensen, J.B. (2007a). Bureaucracy and entrepreneurship: Workplace effects on entrepreneurial entry. Administrative Science Quarterly, 52, 387-412.

Sørensen, J.B. (2007b). Closure versus exposure: Mechanisms in the intergenerational transition of selfemployment. In M. Ruef, \& M. Lounsbury (Eds.), Research in the sociology of organizations (pp. 83124). Amsterdam: JAI Press.

Sørensen, J.B., \& Fassiotto, M.A. (2011). Organizations as fonts of entrepreneurship. Organization Science, 22(5), 1322-1331.

Sørensen, J.B., \& Sharkey, A. (2014). Entrepreneurship as a mobility process. American Sociological Review, 79(2), 328-349.

Sorenson, O., \& Audia, P.G. (2000). The social structure of entrepreneurial activity: Geographic concentration of footwear production in the United States, 1940-1989. American Journal of Sociology, 106(2), $424-462$.

Spilerman, S. (1977). Careers, labor market structure, and socioeconomic achievement. American Journal of Sociology, 83(3), 551-593. 
Thebaud, S. 2016. Passing up the job: The role of gendered organizations and families in the entrepreneurial career process. Entrepreneurship Theory and Practice, 40(2), 269-287.

Toft-Kehler, R., Wennberg, K., \& Kim, P.H. (2014). Practice makes perfect: Entrepreneurial-experience curves and venture performance. Journal of Business Venturing, 29(4), 453-470.

Unger, J.M., Rauch, A., Frese, M., \& Rosenbusch, N. (2011). Human capital and entrepreneurial success: A meta-analytical review. Journal of Business Venturing, 26, 341-358.

Wasserman, N. (2003). Founder-CEO succession and the paradox of entrepreneurial success. Organization Science, 14(2), 149-172.

M. Diane Burton is associate professor of human resource studies, ILR School, Cornell University, 170 Ives Hall, Ithaca, NY 14853.

Jesper B. Sørensen is Robert A. and Elizabeth R. Jeffe Professor of Organizational Behavior, Graduate School of Business, Stanford University, 655 Knight Way, Stanford, CA 94305.

Stanislav D. Dobrev is Robert L. and Sally S. Manegold Chair in Strategic Management, Sheldon B. Lubar School of Business, University of Wisconsin-Milwaukee, Lubar Hall N371, Milwaukee, WI 53201. 